\title{
Protective Effects of Walnut Extract Against Amyloid Beta Peptide-Induced Cell Death and Oxidative Stress in PC12 Cells
}

\author{
Balu Muthaiyah • Musthafa M. Essa • \\ Ved Chauhan - Abha Chauhan
}

Accepted: 10 June 2011/Published online: 25 June 2011

(C) The Author(s) 2011. This article is published with open access at Springerlink.com

\begin{abstract}
Amyloid beta-protein $(\mathrm{A} \beta)$ is the major component of senile plaques and cerebrovascular amyloid deposits in individuals with Alzheimer's disease. $\mathrm{A} \beta$ is known to increase free radical production in neuronal cells, leading to oxidative stress and cell death. Recently, considerable attention has been focused on dietary antioxidants that are able to scavenge reactive oxygen species (ROS), thereby offering protection against oxidative stress. Walnuts are rich in components that have anti-oxidant and anti-inflammatory properties. The inhibition of in vitro fibrillization of synthetic $\mathrm{A} \beta$, and solubilization of preformed fibrillar $\mathrm{A} \beta$ by walnut extract was previously reported. The present study was designed to investigate whether walnut extract can protect against $\mathrm{A} \beta$-induced oxidative damage and cytotoxicity. The effect of walnut extract on $\mathrm{A} \beta$-induced cellular damage, ROS generation and apoptosis in PC12 pheochromocytoma cells was studied. Walnut extract reduced $\mathrm{A} \beta$-mediated cell death assessed by MTT (3-(4,5-dimethylthiazol-2-yl)-2,5-diphenyltetrazolium bromide) reduction, and release of lactate dehydrogenase (membrane damage), DNA damage (apoptosis) and generation of ROS in a concentration-dependent manner. These results suggest that walnut extract can counteract $\mathrm{A} \beta$-induced oxidative stress and associated cell death.
\end{abstract}

Keywords Alzheimer's disease - Amyloid beta-protein . Apoptosis · Cytotoxicity · Oxidative stress · Walnut

B. Muthaiyah · M. M. Essa - V. Chauhan · A. Chauhan ( $\square)$ Department of Neurochemistry, NYS Institute for Basic

Research in Developmental Disabilities, 1050 Forest Hill Road,

Staten Island, NY 10314, USA

e-mail: abha.chauhan@opwdd.ny.gov

\section{Introduction}

Alzheimer's disease (AD) is a severe neurodegenerative disease that gradually results in loss of memory and impairment of cognitive functions in the elderly. The aggregation and fibrillization of amyloid beta-protein (Aß), leading to the deposition of amyloid plaques in the brain, is one of the major pathological features in $\mathrm{AD}[1,2]$. The mechanisms of neuronal cell loss in AD have not yet been fully elucidated, but increased oxidative stress [3-14] and inflammation [5, 14-16] are considered important initiators/mediators of neuronal damage in AD. Extensive evidence indicates that the brains of individuals with $\mathrm{AD}$ are characterized by exaggerated oxidative stress $[3,4,6,7$, $10-13]$, and the overproduction of $\mathrm{A} \beta$ leads to $\mathrm{A} \beta$-associated free-radical production and cell death [17-21]. Not only does $A B$ increase oxidative stress, but its generation is also increased as a result of oxidative stress, which in turn causes more oxidative damage.

$\mathrm{A} \beta$ fibril formation is a multi-step process that is preceded by oligomerization and aggregation of monomeric $\mathrm{A} \beta$, and it involves conformational change of the peptide from alpha-helical to beta-pleated sheet structure [22]. Recent evidence suggests that soluble oligomers of $A B$ in the brain are neurotoxic and a major risk factor for the onset and progression of cognitive deterioration in $\mathrm{AD}$ [23-25].

The potential beneficial roles of dietary antioxidants have been emphasized in various diseases including AD. Walnuts (Juglans regia L.) are an excellent source of $\alpha$-linolenic acid (plant-based omega-3 fatty acid) and have a high content of antioxidants such as flavonoids, phenolic acid (ellagic acid), melatonin, gamma tocopherol and selenium [26-32]. In terms of antioxidant contents, walnuts ranked second among 1,113 different food items tested 
[33]. While most nuts contain monounsaturated fats, walnuts comprise primarily polyunsaturated fat (13 $\mathrm{g}$ of $18 \mathrm{~g}$ total fat in one ounce of walnuts), of which $\alpha$-linolenic acid is $2.5 \mathrm{~g}$.

Green walnuts, shells, kernels and seeds, bark and leaves have been used in the pharmaceutical and cosmetic industries [34]. Walnuts and their leaves have been used in traditional medicine for treatment of venous insufficiency and haemorrhoidal symptomatology, and for their antidiarrheic, anti-microbial, antihelmintic, depurative and astringent properties [35-37]. The keratolytic, antifungal, hypoglycemic, hypotensive and sedative activities of walnuts have also been reported [27, 36]. Several studies have suggested that the consumption of walnuts in the diet can reduce the risk of heart disease [38-41] and decrease total and low-density lipoproteins (LDL) [39, 42-46]. In another study, a polyphenolic-rich extract of walnuts was able to protect LDL from oxidation [26]. A large cohort study of 83,818 women (age: 34-59 years) showed that consumption of one-ounce portions of nuts, such as walnuts, or of peanut butter five times or more each week significantly reduced the risk of developing type 2 diabetes [47]. Animal studies showed that a diet rich in walnuts slowed the growth of MDA-MB231 human breast cancers implanted into nude mice [48], and oral administration of a polyphenolic-rich fraction of walnuts prevented liver damage in mice [49].

An in vitro study has shown that walnut extract can inhibit the fibrillization of synthetic $A \beta$ and also solubilize $\mathrm{A} \beta$ fibrils [50]. Although various phytochemical constituents and diverse medicinal activities have been attributed to walnuts, biochemical studies have not been carried out to study whether walnuts can protect against $\mathrm{A} \beta$-induced cell death. PC12 Pheochromocytoma cells are widely used for in vitro research on AD. These cells contain many membrane-bound and cytosolic molecules associated with neurons, and are electrically excitable and neurosecretory $[51,52]$. The present study was designed to analyze the effect of walnut extract on $\mathrm{A} \beta$-induced cytotoxicity and oxidative damage in PC12 cells.

\section{Experimental Procedure}

\section{Materials}

PC12 cell line was obtained from the American Type Culture Collection (Manassas, VA). A $\beta$ (1-42) was purchased from Anaspec (Fremont, CA). Dimethyl sulfoxide (DMSO) and 3-(4,5-dimethylthiazol-2-yl)-2,5-diphenyltetrazolium bromide (MTT) were purchased from Sigma (St. Louis, MO). Dichlorofluorescin diacetate (DCFHDA), RPMI 1640 medium, horse serum, fetal bovine serum and antibiotic-antimycotic were purchased from Invitrogen (Carlsbad, CA). Cell Death Detection ELISA ${ }^{\text {PLUS }}$ kit was purchased from Roche Applied Science (Indianapolis, IN), and assay kit for lactate dehydrogenase (LDH) was purchased from Promega (Madison, WI). All other chemicals and reagents were from Sigma.

\section{Preparation of Walnut Extract}

The walnut extract was prepared by the modified method of Anderson et al. [26]. In brief, walnuts (30 g; approximately six walnuts) were frozen for $24 \mathrm{~h}$; the shelled kernel was then immersed in $240 \mathrm{ml}$ of $100 \mathrm{mM}$ acetate buffer, $\mathrm{pH}$ 4.8/acetone (30:70, V/V). After incubation at $4{ }^{\circ} \mathrm{C}$ for $24 \mathrm{~h}$, the solutions were decanted, resulting in a cold extract. This process was repeated. The two macerates were combined and concentrated using a rotary evaporator under reduced pressure at $37^{\circ} \mathrm{C}$ until the organic solvent was completely evaporated. The concentrated solution was extracted three times with $75 \mathrm{ml}$ ethyl acetate. The three ethyl acetate extracts were combined and then evaporated to remove ethyl acetate. A lyophilized powder of walnut extract was obtained and dissolved in $25 \mathrm{mM}$ Tris- $\mathrm{HCl}$, $\mathrm{pH} 7.4$.

\section{Measurement of Total Phenolics in Walnut Extract}

To rule out the variation in different walnut preparations, we measured the total phenolics in walnut extract and expressed the concentration of walnut extract in terms of gallic acid equivalent (GAE) to maintain the consistency of samples. Total phenolics were measured by the Folin-Ciocalteu assay [53]. Briefly, the Folin-Ciocalteu reagent was mixed with serial dilutions of walnut extract or gallic acid standards, followed by incubation with $1.9 \mathrm{M}$ sodium carbonate. After $1 \mathrm{~h}$, the absorbance at $765 \mathrm{~nm}$ was measured and compared with that of gallic acid standards. The concentration of phenolics in walnut extract was expressed as GAE.

Aggregation and Fibrillization of Amyloid Beta-Protein

Synthetic A $\beta$ 1-42 was solubilized in $25 \mathrm{mM}$ Tris- $\mathrm{HCl}$, $\mathrm{pH} 7.4$, and allowed to aggregate and fibrillize by incubating at room temperature for $72 \mathrm{~h}$. The beta-pleated structure of $\mathrm{A} \beta$ was confirmed by Thioflavin $\mathrm{T}$ (ThT) fluorescence spectroscopy, as described previously [54]. ThT does not bind to dimers or tetramers, but only binds to higher-order $\mathrm{A} \beta$ aggregates, protofibrils and amyloid-like fibrils $[55,56]$. When ThT binds to $\mathrm{A} \beta$, it fluoresces at the excitation and emission wavelengths of 435 and $485 \mathrm{~nm}$, respectively. 


\section{Cell Culture}

PC12 cells were cultured and maintained as described previously [57]. The growth medium consisted of RPMI $1640,10 \%$ heat-inactivated horse serum, $5 \%$ fetal bovine serum, 50 units $/ \mathrm{ml}$ penicillin and $100 \mathrm{mg} / \mathrm{ml}$ streptomycin. Cultures were maintained in the $37^{\circ} \mathrm{C}$ incubator with water saturated and $5 \% \mathrm{CO}_{2}$. PC12 cells were passaged when the culture was $80-90 \%$ confluent, dislodged from the surface of the culture dish $(100 \mathrm{~mm})$ and dispersed into a single cell by triturating the culture medium directly onto the cells repeatedly and forcefully. The cells were sub-cultured once a week in the split ratio of 1:4. The viability of cells was checked using trypan blue, and $95 \%$ of viable cells were used for all the assays.

Effect of Walnut Extract on $\mathrm{A} \beta$-Induced Cell Death and Oxidative Stress in PC12 Cells

$\mathrm{A} \beta$-mediated toxic effect was measured in the absence or presence of walnut extract in PC12 cells by the following methods.

\section{MTT Reduction Assay for Cell Viability}

Cellular viability was measured in a 96-well plate by quantitative colorimetric assay with MTT, which is an indicator of the mitochondrial activity of living cells [58]. It is reduced to formazan by mitochondrial respiratory enzymes, and therefore, the amount of formazan produced indicates the cell viability. PC12 cells were pretreated with different concentrations of walnut extract ( 2 or $4 \mu \mathrm{g} \mathrm{GAE})$, and then exposed to $50 \mu \mathrm{M}$ or $75 \mu \mathrm{M} \mathrm{A} \beta 1-42$ for $24 \mathrm{~h}$. After the medium was removed, the cells were incubated with $0.25 \mathrm{mg} / \mathrm{ml}$ MTT for $4 \mathrm{~h}$ at $37^{\circ} \mathrm{C}$. The reaction was stopped by adding DMSO. The amount of MTT formazan product was determined by measuring absorbance in a microplate reader at a test wavelength of $570 \mathrm{~nm}$ and a reference wavelength of $630 \mathrm{~nm}$.

\section{LDH Release Assay for Cell Membrane Damage}

LDH released into the medium is an index of cell membrane damage because of the enzyme's high intracellular localization. The plasma membrane damage was evaluated by measuring extracellular LDH activity in the medium. PC12 cells were pretreated with different concentrations of the walnut extract ( 2 or $4 \mu \mathrm{g}$ GAE), and then exposed to 50 or $75 \mu \mathrm{M} \mathrm{A} \beta 1-42$ for $24 \mathrm{~h}$. After the incubation, $50 \mu \mathrm{l}$ of culture supernatants were collected from each well. The LDH activity was determined with a colorimetric LDH assay kit. Total cellular LDH activity was determined by solubilizing the cell with $0.2 \%$ Triton $\mathrm{X}-100$. The release of intracellular LDH to the extracellular medium is expressed as a percentage of total cellular LDH activity.

\section{Assessment of DNA Damage for Apoptosis}

There is enrichment of mono- and oligonucleosomes in the cytoplasm of the apoptotic cells because DNA degradation occurs several hours before plasma membrane breakdown [59]. Assessment of apoptosis was done by using the Cell Death Detection ELISA ${ }^{\text {PLUS }}$ kit. This assay is a photometric enzyme-linked immunoassay, which measures quantitatively the internucleosomal degradation of DNA that occurs during apoptosis. Specifically, the assay detects histone-associated DNA fragments (mono- and oligonucleosomes), which are indicators of apoptosis. PC12 cells were plated at a density of 10,000 cells per well in a 96-well plate, and allowed to attach for $12 \mathrm{~h}$. The cells were treated with walnut extract ( 2 or $4 \mu \mathrm{g} \mathrm{GAE}$ ), and/or $\mathrm{A} \beta(50$ or $75 \mu \mathrm{M})$ for $12 \mathrm{~h}$. Following treatments, adherent cells were washed with PBS (137 mM sodium chloride, $1.5 \mathrm{mM}$ potassium phosphate, $7.2 \mathrm{mM}$ sodium phosphate, $2.7 \mathrm{mM}$ potassium chloride, $\mathrm{pH}$ 7.4). An equal number of live cells was added to the microtiter plate for all treatment groups, and apoptosis assay was performed according to the manufacturer's instructions.

\section{Effect of Walnut Extract on Generation of Free Radicals}

The levels of intracellular reactive oxygen species (ROS) were determined by the change in fluorescence resulting from the oxidation of the fluorescent probe DCFH-DA [60]. When applied to intact cells, DCFH-DA readily diffuses through the cell membrane and is hydrolyzed enzymatically by intracellular esterases to nonfluorescent DCFH [61]. In the presence of ROS, DCFH is oxidized to highly fluorescent DCF [61]. DCF fluorescent intensity is proportional to the amount of ROS formed intracellularly. In this assay, PC12 cells were pretreated with different concentrations of the walnut extract, and then exposed to 50 or $75 \mu \mathrm{M} \mathrm{A} \beta 1-42$ for $24 \mathrm{~h}$. After the medium was removed, the cells were incubated with $100 \mu \mathrm{M}$ DCFH-DA for $30 \mathrm{~min}$, and the cells were washed to remove the extracellular DCFH-DA. The cells were then suspended in PBS. The fluorescence intensity (relative fluorescence unit) was determined using a CytoFluor 4000 fluorescence plate reader at the excitation wavelength of $485 \mathrm{~nm}$ and emission wavelength of $535 \mathrm{~nm}$.

\section{Statistical Analysis}

Data are expressed as mean \pm SD for each group $(n=3)$. The statistical significance of changes in different groups 
was evaluated by one way-ANOVA using GraphPad Prism software. The statistical significance at $P<0.05$ was considered as significant.

\section{Results}

Mean \pm SD for different groups, i.e., control cells (no $\mathrm{A} \beta$ ), $\mathrm{A} \beta$-treated cells, and the effect of different concentrations of walnut extract ( 2 or $4 \mu \mathrm{g}$ GAE) on control and $\mathrm{A} \beta$ treated cells are represented in Figs. 1, 2, 3, 4. Table 1 summarizes the effects of walnut extract on $\mathrm{A} \beta$-induced cell death and free radical generation.

Effect of Walnut Extract on $\mathrm{A} \beta$-Mediated Cytotoxicity in PC12 Cells

$\mathrm{A} \beta$ was found to induce cytotoxicity in $\mathrm{PC} 12$ cells, as judged by MTT assay and LDH release. MTT reduction assay showed that $\mathrm{A} \beta 1-42$ induced cytotoxicity and significantly reduced cell viability $(P<0.001)$ by $60 \%$ at $50 \mu \mathrm{M}$, and by $62.1 \%$ at $75 \mu \mathrm{M}$ concentrations of $\mathrm{A} \beta$ as compared to control cells (no $\mathrm{A} \beta$ ). The pretreatment of the cells with walnut extract ( 2 and $4 \mu \mathrm{g}$ GAE) resulted in the reduction of $\mathrm{A} \beta$-induced cytotoxicity and significantly increased cell viability (Fig. 1; Table 1). These results demonstrate that the walnut extract can protect cells against $\mathrm{A} \beta$-induced cytotoxicity.

Figure 2 represents $\mathrm{A} \beta$-induced $\mathrm{LDH}$ release into the conditioned medium of PC12 cells with or without treatment with walnut extract. LDH assay showed that $\mathrm{A} \beta$ released LDH from the cells in a concentration-dependent manner, which was significantly higher $(P<0.05)$ at $75 \mu \mathrm{M}$ than at $50 \mu \mathrm{M}$ of $\mathrm{A} \beta$ concentration. As shown in Fig. 2 and Table 1 , this effect of $\mathrm{A} \beta$ was significantly

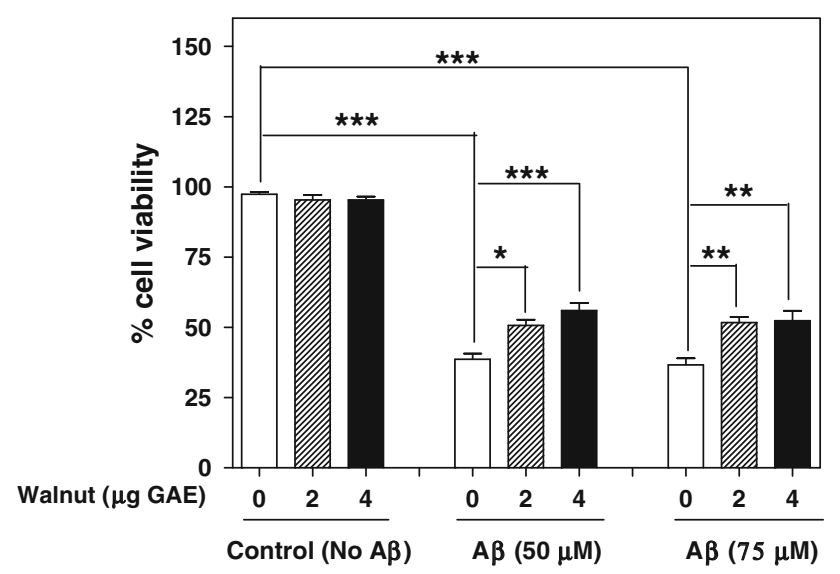

Fig. 1 Effect of different concentrations of walnut extract on $\mathrm{A} \beta$ induced cell death. Cell viability was assessed by MTT reduction assay. $* P<0.05, * * P<0.01$, $* * * P<0.001$, one way-ANOVA

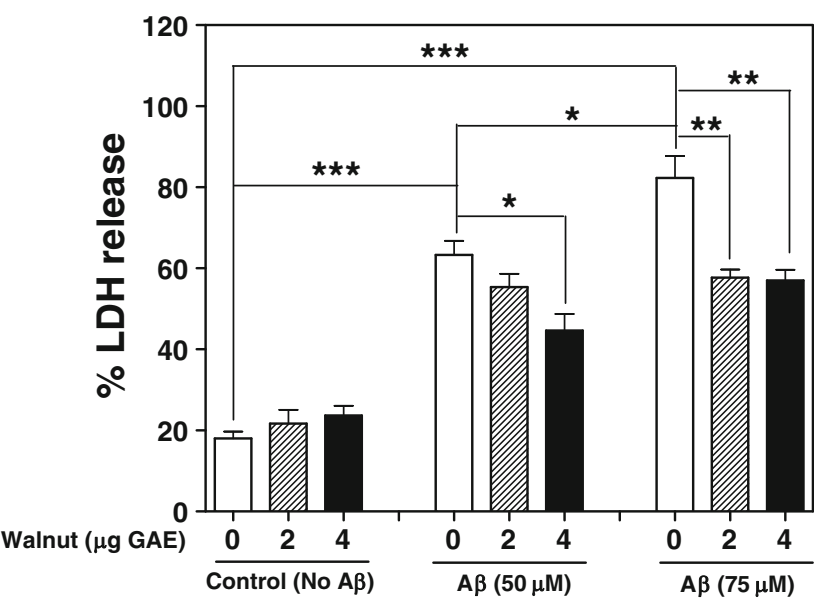

Fig. 2 Effect of different concentrations of walnut extract on $\mathrm{A} \beta$ induced cell membrane damage, assessed by $\mathrm{LDH}$ release. ${ }^{*} P<0.05$, $* * P<0.01, * * * P<0.001$, one way-ANOVA

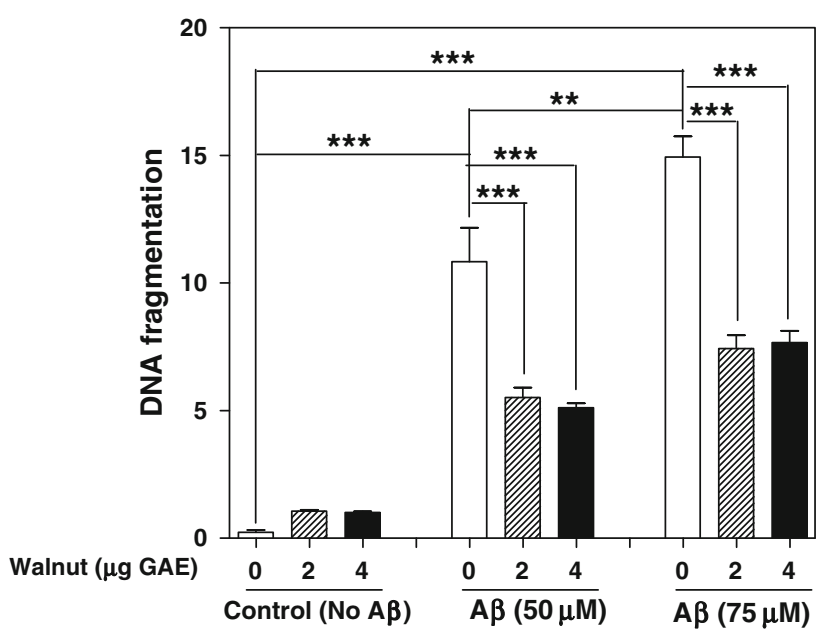

Fig. 3 Effect of different concentrations of walnut extract on $\mathrm{A} \beta$ induced DNA damage in PC12 cells. $* * P<0.01, * * * P<0.001$, one way-ANOVA

inhibited by pretreatment of the cells with walnut extract ( 2 or $4 \mu \mathrm{g}$ GAE). Our results suggest that treatment of the cells with walnut extract protects against $\mathrm{A} \beta$-induced cell membrane damage.

\section{Effect of Walnut Extract on $\mathrm{A} \beta$-Induced DNA Damage} in PC12 Cells

Treatment of PC12 cells with 50 or $75 \mu \mathrm{M} \mathrm{A} \beta$ for $24 \mathrm{~h}$ significantly augmented DNA fragmentation $(P<0.001)$ as compared to control cells that were not treated with $\mathrm{A} \beta$ (Fig. 3; Table 1). This effect was significantly higher at $75 \mu \mathrm{M}$ than at $50 \mu \mathrm{M}$ of $\mathrm{A} \beta$ concentration $(P<0.01)$. The 


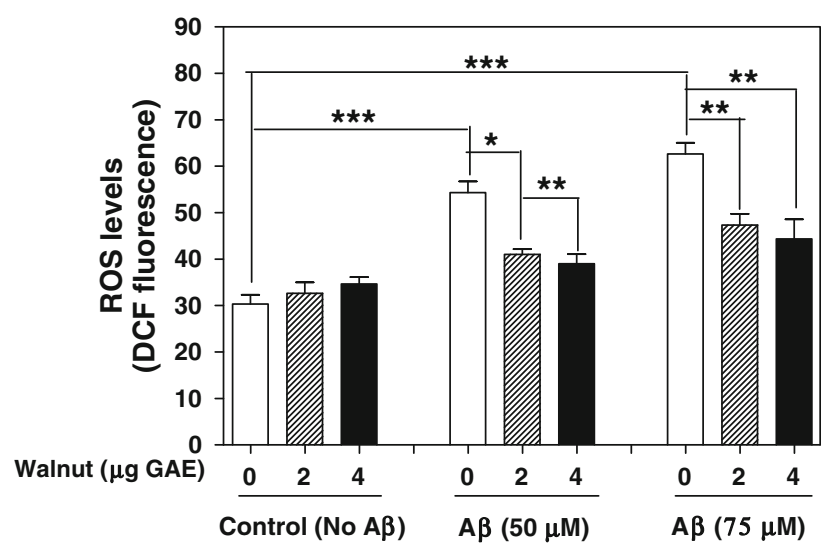

Fig. 4 Effect of different concentrations of walnut extract on $\mathrm{A} \beta$ induced free radical (ROS) generation in PC12 cells. ROS levels were measured by DCF fluorescence assay. $* P<0.05, * * P<0.01$, $* * * P<0.001$, one way-ANOVA

pretreatment of cells with walnut extract ( 2 or $4 \mu \mathrm{g}$ GAE) dramatically reduced the percentage of DNA fragmentation induced by 50 and $75 \mu \mathrm{M} \mathrm{A} \beta \quad(P<0.001)$ (Fig. 3; Table 1). Since DNA fragmentation is indicative of apoptotic cell death, these results suggest that walnuts may prevent apoptosis induced by $\mathrm{A} \beta$.

Walnut Extract Inhibits A $\beta$-Induced Generation of Free Radicals (ROS) in Cells

To examine whether walnut extract can inhibit ROS generation induced by $\mathrm{A} \beta$, we studied the effects of walnut extract on ROS levels in $\mathrm{PC} 12$ cells treated with $\mathrm{A} \beta$ (Fig. 4). Exposure of PC12 cells to 50 or $75 \mu \mathrm{M} \mathrm{A} \beta$ for $24 \mathrm{~h}$ resulted in a significant increase of ROS levels $(P<0.001)$. The cells pretreated with 2 or $4 \mu \mathrm{g}$ GAE of walnut extract showed a significant reduction in the ROS levels. These results indicate that walnut extract can inhibit $\mathrm{A} \beta$-mediated ROS production in PC12 cells.

\section{Discussion}

Oxidative stress [3-14] and inflammation [5, 14-16] are prominent features in the pathophysiology of $\mathrm{AD}$, which may be causally related to neuronal dysfunction and death in AD. The brains of individuals with AD had increased levels of lipid peroxidation products such as 4-hydroxynonenal or 2-propenal, and enhanced lipid peroxidation was also detected in the cerebrospinal fluid and plasma of individuals with $\mathrm{AD}[4,7,10]$. In addition, oxidative damage to proteins and mitochondrial and nuclear DNA is also an important event in AD pathology [4, 8, 11-13]. Increased oxidative damage has also been reported in the early stages of mild cognitive impairment in the brains of individuals with $\mathrm{AD}$, and in cerebrospinal fluid from individuals with very early signs of dementia [14, 62].

The relationship between diet and health benefits has become increasingly obvious with accumulating evidence that plant foods rich in phenols and flavonoids are an important class of defensive antioxidants [63-67]. Plant extracts such as green tea, gingko biloba and curcumin have been reported to prevent oxidative stress-mediated apoptosis in cultured neurons, and also to reduce the oxidative stress that is associated with $\mathrm{AD}$ [67-72]. Walnut extract has been reported to inhibit $\mathrm{A} \beta$ fibrillization and to solubilize $\mathrm{A} \beta$ fibrils [50]. In the present study, we report for the first time that walnut extract acts as a cytoprotective agent against $\mathrm{A} \beta$-induced cytotoxicity.

Several studies have indicated that $\mathrm{A} \beta$ induces apoptosis and neuronal cell death by producing ROS, which leads to the peroxidation of membrane lipids and oxidative stress [17-21]. We also observed that $\mathrm{A} \beta$ induces ROS generation in PC12 cells. Interestingly, the intracellular ROS accumulation resulting from $\mathrm{A} \beta$ treatment was significantly reduced when cells were treated with walnut extract as compared to control cells treated with $\mathrm{A} \beta$ only, which clearly demonstrated that walnut extract has the ability to scavenge oxygen radicals. ROS generation and the

Table 1 Effect of A $\beta$ on cell death, apoptosis and free radical generation in the absence or presence of different concentrations of walnut extract (WE) in PC12 cells

\begin{tabular}{|c|c|c|c|c|c|c|}
\hline \multirow[t]{2}{*}{$\mathrm{A} \beta$-induced changes } & \multicolumn{3}{|c|}{$\mathrm{A} \beta(50 \mu \mathrm{M})$} & \multicolumn{3}{|c|}{$\mathrm{A} \beta(75 \mu \mathrm{M})$} \\
\hline & No WE & $\begin{array}{l}+ \text { WE } \\
(2 \mu \mathrm{g} \text { GAE })\end{array}$ & $\begin{array}{l}+\mathrm{WE} \\
(4 \mu \mathrm{g} \mathrm{GAE})\end{array}$ & $\begin{array}{l}\text { Control } \\
\text { (No WE) }\end{array}$ & $\begin{array}{l}+\mathrm{WE} \\
(2 \mu \mathrm{g} \mathrm{GAE})\end{array}$ & $\begin{array}{l}+ \text { WE } \\
(4 \mu \mathrm{g} G A E)\end{array}$ \\
\hline $\begin{array}{l}\text { LDH release (increase in membrane } \\
\text { damage) }\end{array}$ & $251.8 \%$ & $155.4 \%$ & $88.7 \%$ & $357.3 \%$ & $166.2 \%$ & $140.9 \%$ \\
\hline MTT (decrease in cell viability) & $-60.0 \%$ & $-46.8 \%$ & $-41.2 \%$ & $-62.1 \%$ & $-47.8 \%$ & $-45.1 \%$ \\
\hline $\begin{array}{l}\text { Apoptosis (fold increase in DNA } \\
\text { fragmentation) }\end{array}$ & 47.1 & 5.2 & 5.1 & 64.9 & 7.0 & 7.6 \\
\hline ROS (increase in free radical generation) & $79.1 \%$ & $25.5 \%$ & $12.5 \%$ & $106 \%$ & $44.9 \%$ & $27.9 \%$ \\
\hline
\end{tabular}

The effect of $\mathrm{A} \beta$ on LDH release, MTT reduction, DNA fragmentation and ROS levels in the absence or presence of walnut extract is calculated in comparison to controls (no $\mathrm{A} \beta$ ) 
resultant oxidative stress have been implicated widely in the mechanism of $\mathrm{A} \beta$-induced cell death. It is also known that flavonoids, ellagic acid, melatonin and gamma tocopherol, which are components of walnuts [26-32], have antioxidative and free-radical scavenging properties [63-67, 73, 74]. Because constituents of walnuts have strong antioxidant properties, it is suggested that inhibition of $\mathrm{A} \beta$-induced free radical generation by walnut extract may be due to the neutralization of ROS. It has been suggested that flavonols and polyphenols can interact with membrane phospholipids through hydrogen bonding to the polar head groups of phospholipids, and thus protect the integrity of the cell membrane from oxidative damage [75].

An upsurge in ROS production can also cause shifts in the redox state of cells, which is associated with the apoptotic pathway [76]. The increased reduction of MTT and release of LDH upon treatment of the cells with $\mathrm{A} \beta$ that we observed suggests that $\mathrm{A} \beta$ affects cell viability and membrane damage. In addition, $\mathrm{A} \beta$ induced DNA fragmentation in the cells that is indicative of apoptosis. Our findings of $\mathrm{A} \beta$-mediated cytotoxicity and of DNA and membrane damage are suggestive of the involvement of apoptosis in $\mathrm{A} \beta$-induced cell death. The treatment with walnut extract significantly increased cell viability, reduced the apoptosis induced by $\mathrm{A} \beta$ and offered protection in PC12 cells. This protective effect of walnut extract against $\mathrm{A} \beta$-mediated cytotoxicity in $\mathrm{PC} 12$ cells may be attributed to the anti-oxidative capacity of different constituents of walnuts.

The beneficial effects of walnuts have also been implicated in reducing the risk of coronary heart disease and coronary vascular disease [38-41]. In addition, the potential benefits of consumption of nuts in lowering the risk of type 2 diabetes in women has been reported [47]. The role of oxidative stress in the onset and progression of diabetes is well documented. Some of the effects of the oxidative environment include the development of insulin resistance, dysfunction of the $\beta$ cells of the pancreas, impaired glucose tolerance and mitochondrial dysfunction, which may lead to the diabetic condition [77]. Several studies have suggested an inverse relationship between insulin sensitivity and ROS levels. Reduction in oxidative stress by a diet rich in walnuts may also help improve insulin sensitivity and glucose metabolism.

In summary, our results suggest that walnut extract offers protection against $\mathrm{A} \beta$ - mediated cell death by (1) reducing the generation of free radicals, (2) inhibiting membrane damage and (3) attenuating DNA damage. This effect of walnut extract could be due to the active compounds present in walnuts, which may increase the capacity of endogenous antioxidant defenses and may modulate the cellular redox state. A diet rich in walnuts may therefore reduce $\mathrm{A} \beta$-mediated cytotoxicity, neuronal loss and the risk of developing $\mathrm{AD}$.

Acknowledgments This work was supported in part by funds from the New York State Office for People with Developmental Disabilities, and the California Walnut Commission.

Open Access This article is distributed under the terms of the Creative Commons Attribution Noncommercial License which permits any noncommercial use, distribution, and reproduction in any medium, provided the original author(s) and source are credited.

\section{References}

1. Glenner GG (1983) Alzheimer's disease. The commonest form of amyloidosis. Arch Pathol Lab Med 107:281-282

2. Masters CL, Simms G, Weinman NA et al (1985) Amyloid plaque core protein in Alzheimer disease and Down syndrome. Proc Natl Acad Sci USA 82:4245-4249

3. Bonda DJ, Wang X, Perry G et al (2010) Oxidative stress in Alzheimer disease: a possibility for prevention. Neuropharmacology 59:290-294

4. Chauhan V, Chauhan A (2006) Oxidative stress in Alzheimer's disease. Pathophysiology 13:195-208

5. Galasko D, Montine TJ (2010) Biomarkers of oxidative damage and inflammation in Alzheimer's disease. Biomark Med 4:27-36

6. Gibson GE, Huang HM (2002) Oxidative processes in the brain and non-neuronal tissues as biomarkers of Alzheimer's disease. Front Biosci 7:d1007-d1015

7. Montine TJ, Neely MD, Quinn JF et al (2002) Lipid peroxidation in aging brain and Alzheimer's disease. Free Radic Biol Med 33:620-626

8. Nunomura A, Tamaoki T, Tanaka K et al (2010) Intraneuronal amyloid beta accumulation and oxidative damage to nucleic acids in Alzheimer disease. Neurobiol Dis 37:731-737

9. Perry G, Nunomura A, Hirai K et al (2002) Is oxidative damage the fundamental pathogenic mechanism of Alzheimer's and other neurodegenerative diseases? Free Radic Biol Med 33:1475-1479

10. Arlt S, Beisiegel U, Kontush A (2002) Lipid peroxidation in neurodegeneration: new insights into Alzheimer's disease. Curr Opin Lipidol 13:289-294

11. Lyras L, Cairns NJ, Jenner A et al (1997) An assessment of oxidative damage to proteins, lipids, and DNA in brain from patients with Alzheimer's disease. J Neurochem 68:2061-2069

12. Gabbita SP, Lovell MA, Markesbery WR (1998) Increased nuclear DNA oxidation in the brain in Alzheimer's disease. J Neurochem 71:2034-2040

13. Lovell MA, Gabbita SP, Markesbery WR (1999) Increased DNA oxidation and decreased levels of repair products in Alzheimer's disease ventricular CSF. J Neurochem 72:771-776

14. Steele M, Stuchbury G, Munch G (2007) The molecular basis of the prevention of Alzheimer's disease through healthy nutrition. Exp Gerontol 42:28-36

15. Rozemuller AJ, van Gool WA, Eikelenboom P (2005) The neuroinflammatory response in plaques and amyloid angiopathy in Alzheimer's disease: therapeutic implications. Curr Drug Targets CNS Neurol Disord 4:223-233

16. Schwab C, McGeer PL (2008) Inflammatory aspects of Alzheimer disease and other neurodegenerative disorders. Alzheimers Dis 13:359-369

17. Harris ME, Hensley K, Butterfield DA et al (1995) Direct evidence of oxidative injury produced by the Alzheimer's beta- 
amyloid peptide (1-40) in cultured hippocampal neurons. Exp Neurol 131:193-202

18. Hensley K, Butterfield DA, Mattson M et al (1995) A model for beta-amyloid aggregation and neurotoxicity based on the free radical generating capacity of the peptide: implications of "molecular shrapnel" for Alzheimer's disease. Proc West Pharmacol Soc 38:113-120

19. Kadowaki H, Nishitoh H, Urano F et al (2005) Amyloid beta induces neuronal cell death through ROS-mediated ASK1 activation. Cell Death Differ 12:19-24

20. Monji A, Utsumi H, Ueda $\mathrm{T}$ et al (2001) The relationship between the aggregational state of the amyloid-beta peptides and free radical generation by the peptides. J Neurochem 77:14251432

21. Sponne I, Fifre A, Drouet B et al (2003) Apoptotic neuronal cell death induced by the non-fibrillar amyloid-beta peptide proceeds through an early reactive oxygen species-dependent cytoskeleton perturbation. J Biol Chem 278:3437-3445

22. Dasilva KA, Shaw JE, McLaurin J (2010) Amyloid-beta fibrillogenesis: structural insight and therapeutic intervention. Exp Neurol 223:311-321

23. Lesne S, Koh MT, Kotilinek L et al (2006) A specific amyloidbeta protein assembly in the brain impairs memory. Nature 440:352-357

24. Ono K, Condron MM, Teplow DB (2009) Structure-neurotoxicity relationships of amyloid beta-protein oligomers. Proc Natl Acad Sci USA 106:14745-14750

25. Sakono M, Zako T (2010) Amyloid oligomers: formation and toxicity of Abeta oligomers. FEBS J 277:1348-1358

26. Anderson KJ, Teuber SS, Gobeille A et al (2001) Walnut polyphenolics inhibit in vitro human plasma and LDL oxidation. J Nutr 131:2837-2842

27. Fukuda T, Ito H, Yoshida T (2003) Antioxidative polyphenols from walnuts (Juglans regia L.). Phytochemistry 63:795-801

28. Jurd L (1956) Plant polyphenols. 1. The polyphenolic constituents of the walnut (Juglans regia). J Am Chem Soc 78:34453448

29. Amaal JS, Alves MR, Seabra RM et al (2005) Vitamin E composition of walnuts (Juglans regia L.): a 3-year comparative study of different cultivars. J Agric Food Chem 29:5467-5472

30. Lavedrine F, Ravel A, Poupard A et al (1997) Effect of geographic origin, variety and storage on tocopherol concentrations in walnuts by HPLC. Food Chem 58:135-140

31. Jurd L (1958) Plant polyphenols. III. The isolation of a new ellagitannin from the pellicle of the walnut. J Am Chem Soc 80:2249-2252

32. Reiter RJ, Manchester LC, Tan DX (2005) Melatonin in walnuts: influence on levels of melatonin and total antioxidant capacity of blood. Nutrition 21:920-924

33. Halvorsen BL, Carlsen MH, Phillips KM et al (2006) Content of redox-active compounds (i.e., antioxidants) in foods consumed in the United States. Am J Clin Nutr 84:95-135

34. Stampar F, Solar A, Hudina M et al (2006) Traditional walnut liqueur-cocktail of phenolics. Food Chem 95:627-631

35. Oliveira I, Sousa A, Ferreira IC et al (2008) Total phenols, antioxidant potential and antimicrobial activity of walnut (Juglans regia L.) green husks. Food Chem Toxicol 46:2326-2331

36. Pereira JA, Oliveira I, Sousa A et al (2007) Walnut (Juglans regia L.) leaves: phenolic compounds, antibacterial activity and antioxidant potential of different cultivars. Food Chem Toxicol 45:2287-2295

37. Pereira JA, Oliveira I, Sousa A et al (2008) Bioactive properties and chemical composition of six walnut (Juglans regia L.) cultivars. Food Chem Toxicol 46:2103-2111

38. Fraser GE, Sabate J, Beeson WL et al (1992) A possible protective effect of nut consumption on risk of coronary heart disease. The Adventist health study. Arch Intern Med 152:1416-1424

39. Banel DK, Hu FB (2009) Effects of walnut consumption on blood lipids and other cardiovascular risk factors: a meta-analysis and systematic review. Am J Clin Nutr 90:56-63

40. Hu FB, Stampfer MJ, Manson JE et al (1998) Frequent nut consumption and risk of coronary heart disease in women: prospective cohort study. BMJ 317:1341-1345

41. Feldman EB (2002) The scientific evidence for a beneficial health relationship between walnuts and coronary heart disease. J Nutr 132:1062S-1101S

42. Chisholm A, Mann J, Skeaff M et al (1998) A diet rich in walnuts favourably influences plasma fatty acid profile in moderately hyperlipidaemic subjects. Eur J Clin Nutr 52:12-16

43. Abbey M, Noakes M, Belling GB et al (1994) Partial replacement of saturated fatty acids with almonds or walnuts lowers total plasma cholesterol and low-density-lipoprotein cholesterol. Am J Clin Nutr 59:995-999

44. Rajaram S, Haddad EH, Mejia A et al (2009) Walnuts and fatty fish influence different serum lipid fractions in normal to mildly hyperlipidemic individuals: a randomized controlled study. Am J Clin Nutr 89:1657S-1663S

45. Sabate J, Fraser GE, Burke K et al (1993) Effects of walnuts on serum lipid levels and blood pressure in normal men. N Engl J Med 328:603-607

46. Zambon D, Sabate J, Munoz S et al (2000) Substituting walnuts for monounsaturated fat improves the serum lipid profile of hypercholesterolemic men and women. A randomized crossover trial. Ann Intern Med 132:538-546

47. Jiang R, Manson JE, Stamfer MJ et al (2002) Nut and peanut butter consumption and risk of type 2 diabetes in women. JAMA 288:2554-2560

48. Hardman WE, Ion G (2008) Suppression of implanted MDA-MB 231 human breast cancer growth in nude mice by dietary walnut. Nutr Cancer 60:666-674

49. Shimoda H, Tanaka J, Kikuchi M et al (2008) Walnut polyphenols prevent liver damage induced by carbon tetrachloride and d-galactosamine: hepatoprotective hydrolyzable tannins in the kernel pellicles of walnut. J Agric Food Chem 56:4444-4449

50. Chauhan N, Wang KC, Wegiel J et al (2004) Walnut extract inhibits the fibrillization of amyloid beta-protein, and also defibrillizes its preformed fibrils. Curr Alzheimer Res 1:183-188

51. Park JW, Youn YC, Kwon OS et al (2002) Protective effect of serotonin on 6-hydroxydopamine- and dopamine-induced oxidative damage of brain mitochondria and synaptosomes and PC12 cells. Neurochem Int 40:223-233

52. Shafer TJ, Atchison WD (1991) Transmitter, ion channel and receptor properties of pheochromocytoma (PC12) cells: a model for neurotoxicological studies. Neurotoxicology 12:473-492

53. Singleton VL, Orthofer R, Lamuela-Ravento RM (1999) Analysis of total phenols and other oxidation substrates and antioxidants by means of Folin-Ciocalteu reagent. Methods Enzymol 299:152-178

54. Chauhan A, Pirttila T, Mehta P et al (1996) Effect of cerebrospinal fluid from normal and Alzheimer's patients with different apolipoprotein $\mathrm{E}$ phenotypes on in vitro aggregation of amyloid beta-protein. J Neurol Sci 141:54-58

55. LeVine H III (1993) Thioflavine T interaction with synthetic Alzheimer's disease beta-amyloid peptides: detection of amyloid aggregation in solution. Protein Sci 2:404-410

56. LeVine H III (1995) Soluble multimeric Alzheimer beta (1-40) pre-amyloid complexes in dilute solution. Neurobiol Aging $16: 755-764$

57. Ji L, Chauhan A, Chauhan V (2008) Cytoplasmic gelsolin in pheochromocytoma-12 cells forms a complex with amyloid betaprotein. Neuroreport 19:463-466 
58. Denizot F, Lang R (1986) Rapid colorimetric assay for cell growth and survival. Modifications to the tetrazolium dye procedure giving improved sensitivity and reliability. J Immunol Methods 89:271-277

59. Bonfoco E, Krainc D, Ankarcrona M et al (1995) Apoptosis and necrosis: two distinct events induced, respectively, by mild and intense insults with $N$-methyl-D-aspartate or nitric oxide/superoxide in cortical cell cultures. Proc Natl Acad Sci USA 92:7162-7166

60. Wang H, Joseph JA (1999) Quantifying cellular oxidative stress by dichlorofluorescein assay using microplate reader. Free Radic Biol Med 27:612-616

61. LeBel CP, Ischiropoulos H, Bondy SC (1992) Evaluation of the probe $2^{\prime}, 7^{\prime}$-dichlorofluorescin as an indicator of reactive oxygen species formation and oxidative stress. Chem Res Toxicol 5:227-231

62. Keller JN, Schmitt FA, Scheff SW et al (2005) Evidence of increased oxidative damage in subjects with mild cognitive impairment. Neurology 64:1152-1156

63. Atmani D, Chaher N, Atmani D (2009) Flavonoids in human health: from structure to biological activity. Curr Nutr Food Sci 5:225-237

64. Darvesh AS, Carroll RT, Bishayee A et al (2010) Oxidative stress and Alzheimer's disease: dietary polyphenols as potential therapeutic agents. Expert Rev Neurother 10:729-745

65. Gutierrez-Merino C, Lopez-Sanchez C, Lagoa R et al (2011) Neuroprotective actions of flavonoids. Curr Med Chem 18:11951212

66. Pietta PG (2000) Flavonoids as antioxidants. J Nat Prod 63:1035-1042

67. Rice-Evans CA, Miller NJ, Bolwell PG et al (1995) The relative antioxidant activities of plant-derived polyphenolic flavonoids. Free Radic Res 22:375-383
68. Ahmed T, Gilani AH, Hosseinmardi N et al (2011) Curcuminoids rescue long-term potentiation impaired by amyloid peptide in rat hippocampal slices. Synapse 66:572-582

69. He Y, Cui J, Lee JC et al (2011) Prolonged exposure of cortical neurons to oligomeric amyloid-beta impairs NMDA receptor function via NADPH oxidase-mediated ROS production: protective effect of green tea (-)-epigallocatechin-3-gallate. ASN Neurol 3:13-24

70. Mishra S, Mishra M, Seth P et al (2011) Tetrahydrocurcumin confers protection against amyloid beta-induced toxicity. Neuroreport 22:23-27

71. Park SY, Kim HS, Cho EK et al (2008) Curcumin protected PC12 cells against beta-amyloid-induced toxicity through the inhibition of oxidative damage and tau hyperphosphorylation. Food Chem Toxicol 46:2881-2887

72. Xin W, Wei T, Chen C et al (2000) Mechanisms of apoptosis in rat cerebellar granule cells induced by hydroxyl radicals and the effects of EGb761 and its constituents. Toxicology 148:103-110

73. Pappolla MA, Chyan YJ, Poeggeler B et al (2000) An assessment of the antioxidant and the antiamyloidogenic properties of melatonin: implications for Alzheimer's disease. J Neural Transm 107:203-231

74. Majid S, Khanduja KL, Gandhi RK et al (1991) Influence of ellagic acid on antioxidant defense system and lipid peroxidation in mice. Biochem Pharmacol 42:1441-1445

75. Verstraeten SV, Keen CL, Schmitz HH et al (2003) Flavan-3-ols and procyanidins protect liposomes against lipid oxidation and disruption of the bilayer structure. Free Radic Biol Med 34:84-92

76. Schafer FQ, Buettner GR (2001) Redox environment of the cell as viewed through the redox state of the glutathione disulfide/ glutathione couple. Free Radic Biol Med 30:1191-1212

77. Rains JL, Jain SK (2011) Oxidative stress, insulin signaling, and diabetes. Free Radic Biol Med 50:567-575 